\title{
Discussing the Relationships between Consumer Experiential Value, Celebrity Endorsement and Brand Resonance - Case Study of the STAYREAL Brand
}

\author{
Yun Wang ${ }^{1} \&$ Yu-Tzu Lin ${ }^{2}$ \\ ${ }^{1}$ Department of Fashion Design and Management, College of Management, National Pingtung University of \\ Science and Technology, Pingtung, Taiwan, R. O. C. \\ Correspondence: Yun Wang, \#1, Shuehfu Rd., Neipu, Pingtung 91201, Taiwan, R. O. C.
}

Received: June 16, 2021

Accepted: July 1, 2021

Available online: July 9, 2021

doi:10.5539/ibr.v14n8p26

URL: https://doi.org/10.5539/ibr.v14n8p26

\begin{abstract}
Based on the perspective of concert experience marketing, this research explores whether consumers resonate with the brand STAYREAL through celebrity endorsements while using the P-O-X theory as the research's structure. Research subjects are audiences who have participated in the Mayday concerts. Mall-intercepts method with intentional sampling is used and questionnaires were distributed at the "Super Slippa- part 9" and "The Great Nobody" of 831 rock band in 2018 at the Taipei Arena. 422 valid questionnaires were returned from the 469 distributed. Data were analyzed using the statistical software SPSS19.0 and it was found that: 1 . Experience value has a significant positive impact on celebrity endorsements; 2 . Experience value has a significant positive impact on brand resonance. 3. Celebrity endorsements have a significant positive impact on brand resonance; 4 . Celebrity endorsements have a partial intermediary effect between experience value and brand resonance, which proves that $\mathrm{P}-\mathrm{O}-\mathrm{X}$ is in a balanced state. In order to reach a stage of consumers' resonance with the brand, future research can examine the utility factors such as brand attributes in price, design, fabric, comfort, color, etc. at the same time.
\end{abstract}

Keywords: brand resonance, celebrity endorsement, experience value, Mayday, P-O-X theory, STAYREAL

\section{Introduction}

\subsection{Music Entertainment}

Technology developments have changed people's music consumption. Early in the 70 and 80 s, music listeners went from buying vinyl records, audio tapes, cassettes and CDs to downloading MP3 music files by the end of the 90s due to the increasingly popular use of the internet. Streaming and purchasing audio or audiovisual music through online music platforms or YouTube became part of almost everyone's daily life, which enters different cultural and social levels in the form of personal entertainment (Vogel, 1998). A survey by Taiwan's Ministry of Cultural estimated total profits of Taiwan's popular music in 2011 at NT\$10,292 billion, of which music entertainment companies contributed about NT $\$ 3,015$ billion, digital music service companies about NT $\$ 1,610$ billion, and live performances about NT $\$ 3,640$ billion (Ministry of Cultural, 2013). Consumers' reception of audio visual music no longer focuses on auditory satisfaction brought by physical music products, but also involves live music performances which target consumers' experience of music. The rise of music performance activities illustrates the advent of the experience generation. Pine and Gilmore (1998) discussed the 21st century as the era of the "experience economy". Singers, actors, dancers, etc. are experience providers, although the service experience they provide disappears at the end of the shows, lasting memories are created yielding irreplaceable consumers' experience value.

\subsection{Mayday Band and STAYREAL Brand}

A concert is a dynamic form of live event which allows customers to explore, discover, think, and act in a set theme environment like the experiential marketing of the brand industry. Coupled with the sound and light effects of the concert, the elaborated stage design and the on-site atmosphere create the multi-sensory stimulating experience of the viewers generating the overall value of the concert through inner reverberation touched by the experience and leading to the potential for re-purchase intentions or motivations. Mayday is a Taiwanese rock band named the "Asian Rock Group" and "King of Concerts", and the group began to write the prelude to a long concert career 
from its first large concert "The 168th Concert" in 1999. Later in 2004 they started holding world tour concerts such as "Final Home ", "Leave the Earth Surface", "DNA Creation", "Just Rock it!", "Noah's Ark", "LIFE Unlimited Company" and "Fly to 2021" until 2020. The accumulated number of concerts in the past 20 years has exceeded hundreds, and the number of people in attendance was estimated to have reached 7 million. According to a 2017 report, the Mayday concert cooperated with the convenience store FamilyMart, using their mobile app as a pre-purchase method combined with the pop-up merchandise in store before the concerts, generating a performance income of approximately NT\$10 million (Zhao, 2017). The concerts increased consumers' willingness to purchase records and singers related merchandises. Chen Hing-Hung, nicknamed Ashin, is a singer-songwriter, author and the vocalist of the Taiwanese rock band Mayday. With a major in art in college where he also began his musical career, he founded and designed the clothing line STAYREAL in 2007 with his high school classmate and well-known illustrator Chen Po-Liang (Fuji-Liang). Using his popularity as an asset, he endorsed the brand. Mayday members would also wear STAYREAL apparels on stage, using performances as an advertising mode to promote the brand. Therefore, STAYREAL products are sold alongside music-related merchandises during the concerts.

\subsection{Relevant Research}

Jia, Hung, and Zhang (2017) found that through individual and organized activities, fans support a celebrity directly with their consumption activities such as attending a concert, watching a movie, and buying mementos. Additionally, fans support indirectly via the purchase of celebrity-endorsed products. Other researchers indicated customers' purchase intentions depend mainly on customers' attitudes toward the celebrity's venture brand. Their perceived congruence between a celebrity and the celebrity's business significantly affects their brand attitudes. Additionally, it is found that a celebrity's credibility contributes to increase fans' positive attitudes toward the celebrity's venture brand (Teng, Su, Liao, \& Wei, 2020). Chen (2015) discussed the Brazilian supermodel Gisele as Under Armour's endorser, establishing the brand to successfully enter the women's sports apparel market and the well-known tennis star Nadal endorsing the American leisure brand Tommy Hilfiger (underwear and perfume), pointing at the self-confidence exuded by the celebrities. The endorser's attitude can convey the spirit of the brand and successfully trigger consumers' image associations about uses of goods. When celebrity's attractiveness, expertise, and trustworthiness were assessed, celebrity attractiveness appeared to have the strongest influence on air travelers' brand passion via relatedness need satisfaction (Gilal, Paul, Gilal, \& Gilal, 2020). Drawing from the $\mathrm{P}-\mathrm{O}-\mathrm{X}$ theory, this research explores whether consumers' "experience value" in concerts will affect the image of "celebrity endorsements", and whether celebrity endorsements will affect consumers' resonance with brands. It is expected that exploring the relationship between the three concepts will provide a reference for the apparel and related industries to formulate appropriate marketing strategies, and thereby obtain theoretical confirmation.

\section{Literature Review}

\subsection{P-O-X Balance Theory}

The balance theory, also known as the P-O-X theory, was proposed by the social psychologist Heider in the psychology of motivation as an attitude change theory where $\mathrm{P}$ represents oneself, $\mathrm{O}$ is the other party, and $\mathrm{X}$ is a third party or attitude object between P and O. Heider (1958) believed that individuals' attitudes or beliefs about people and things in their environment can maintain balanced state if a set of cognitive elements is seen as being a system, otherwise they will feel uneasy due to imbalance. The achievement of cognitive balance is dependent on the existence of three positive (like) links or two negative (dislike) and one positive links in the triadic relationships between the three sides. In contrast to what is previously stated, the existence of two positive and one negative links lead to cognitive dissonance or imbalance. The application of the balance theory reveals the emotional connection between consumers and advertising spokespersons, consumers and products, and the bond between advertising spokespersons and products. In recommended advertising, it is suggested that the spokesperson's attitude towards the product in the advertisement must be "positive". In addition, the relationship between the advertising spokesperson and consumers is believed to also be "positive". Thus, in the triadic relationship between spokesperson, consumers and the product, the relationship between consumers and the product can be influenced by advertising. When consumers have a good impression of the advertising spokesperson, there is a close bond between the spokesperson and the product, and consumers do not reject the product, the effect of the spokesperson's recommendation is very significant because the cognitive consistency will strengthen consumers' goodwill towards the product. Conversely, if the consumer dislikes the product but has a good impression of the advertising spokesperson, then the consumer is in a state of cognitive imbalance. The psychological anxiety caused by the imbalance drives him to change his cognition structure, that is, to reduce the favorability of the spokesperson or increase the favorability of the product. 
Russell and Stern (2006) used Heider's theory examined the influence of product placements in television serial comedies on consumer attitudes toward the products. Their results found attitude alignments for links between sitcom character and the placed. Wang (2008) studied the relationship between the characteristics of spokespersons and apparel attributes on the advertising attitudes of the $\mathrm{X}$ and $\mathrm{Y}$ generations using the balance theory, and the research showed that the characteristics of spokespersons significantly affected consumers' advertising attitudes and apparel attributes in both generations. Ho (2013) used the balance theory with cultural proximity and found a positive relationship between consumers, K-pop singers and destination imagery. It also pointed out that strengthening the relationship between celebrities and objects will have a positive attraction to consumers' impression, which means that the triadic relationships in the balance theory are in a balanced state. Han, Seo and Ko (2017) used Heider's balance theory and consumer luxury brand experiences to reveal how a state of psychological imbalance causes the attitude-behavior gap between sustainable fashion and sustainable fashion products consumption (SFPC) behaviors. Participatory action investigation of SFPC in South Korea demonstrated that developing and staging consumer-centered experiences help balance the psychological imbalance occurring in the attitude-behavior gap between sustainability concerns and SFPC behaviors.

\subsection{Experiential Value}

Holbrook and Hirschman's (1982) view of consumption experience stems partially from the limitations of cognitive frameworks that served as the dominant models to explain consumer behavior until the 1980s. They proposed to understand consumer behavior through an experiential model - namely, the thought-emotionactivity-value model. In this sequential model, thought refers to dreams, imagination and fantasy; emotion includes all forms of feelings, sensations, expressive behaviors and physiological responses; activity includes all physical and mental events; and value refers to the final evaluative judgment. Later on, researchers have tried to propose integrative models to provide a more complete view of the literature, such as, the consciousness emotion value model (Holbrook, 1986), the dynamic model of affective response (Cohen \& Areni, 1991), and the experiential decision model (Kwortnik \& Ross, 2007). Zeithaml (1988) believes that value is the subjective evaluation of the consumer during the consumption process. If a customer perceives the "obtained" value as greater than the "paid" value for a specific good or service, this will generate positive value to this customer. Pine and Gilmore (1998) believe experience is an activity enterprises provide consumers with, an environment where "service is the stage and goods are the props" creating a connection with consumers' emotional value leading to the experience of unforgettable memories. The retail stores where offer some thematization atmosphere are the most likely to elicit an experience and represent an escape for people who want to find some fun in their everyday lives (Kaltcheva \& Weitz, 2006). Varshneya, Das and Khare (2017) discussed customer value as the value constituted by consumers' beliefs, attitudes and experience of products. Researchers have demonstrated how the role of experience can enhance customer loyalty through value (Mathwick, Malhotra \& Rigdon, 2002; Terblanche, 2018). This view of experience as a determinant of value creation derives from the foundation of the experiential paradigm, with Holbrook (1999) conceptualizing experience as an interactive, relativistic preference that underlies the creation of all customer value. Likewise, Helkkula, Kelleher and Pihlström (2012) study merges the two concepts into a single concept referred to as "value in the experience" or "value that is directly or indirectly experienced by service customers within their phenomenological lifeworld contexts" (p. 61). In that specific case, value is an experience in itself, rather than an outcome of the experience. Sheth, Newman and Gross (1991) studied how consumers choose to purchase goods and suggested that consumers' choice behavior will be affected by five types of consumption values. (1) Functional value indicates factors that refer to the functional usability or performance of products and services which derive from attributes such as durability, reliability, price of commodities, etc. (2) Social Value is the perception generated by the connection between a product or service and a social group such as demographics, socioeconomics, culture, and is also related to personal self-image and evaluation (Sweeney \& Soutar, 2001). (3) Emotional Value refers to products or services that induce consumer feelings or emotional states. (4) Epistemic Value is related to products or services that stimulate consumers' desire for knowledge and provide novel experiences. Knowledge is considered to be an important characteristic that affects the decision-making process in consumer research (Laroche, Bergeron \& Barbaro-Forleo, 2001). (5) Conditional Value refers to the use value of a product or service in a certain state or special environmental conditions, and in some aspects it also provides functional and social value.

Pine and Gilmore (1998) suggest that experience economy can be divided into four realms across active/passive dimensions. (1) Entertainment experience: Consumers passively participate as observers, which will produce entertainment experience, but their attention is completely attracted by the experience, most of the connection with the event is more absorption than immersion. For example, watching TV or attending a concert, etc., the experience generated by receiving stimulation through the senses. (2) Educational experience: When consumers 
actively participate in events and fully focus on the experience, an educational experience will occur. For example, taking a course or participating in a skiing activity, but most students choose to be outside of the event rather than immersed in it. (3) Escapist experience: When consumers actively participate in activities, an escapist experience will occur, and they are experiencing part of the experience physically or in a virtual state. Consumers actively participate and immerse themselves in events, such as orchestra performance or participation in extreme events. (4) Aesthetic experience: When consumers play the passive role of the observer and experience part of the physical or virtual experience, an aesthetic experience will appear. Customers are immersed in an event or environment, but it does not affect the event itself, such as tourists watching the wonders of the Grand Canyon or visiting a museum, a gallery. Sweeney and Soutar (2001) developed a 19-item measure, the perceived value (PERVAL) scale covering four dimensions: emotional, social, quality/performance and price/money value, and confirm that consumers' consumption value drives consumers' attitudes and purchase behavioral in shopping context. Another experiential value scale (EVS) developed by Mathwick et al. (2002) study of online and catalog shopping based on the consumer value dimension which integrating the "external/internal" and "active/passive" values dimensions to develop an experiential value matric applicable to the retail industry's shopping into four sources: consumer return on investment, playfulness, aesthetics response and service excellence.

\subsection{Celebrity Endorsements}

The study found there is a positive pay-off to a firm's decision to sign an endorser, and that endorsements are associated with increasing sales. Furthermore, sales and stock returns jump noticeably with each major achievement by the athlete (Elberse \& Verleun, 2012). According to Freiden (1984), spokespersons can be divided into four categories, namely celebrities, experts, senior managers of companies and typical consumers. Derdenger, $\mathrm{Li}$, and Srinivasan (2018) investigate how celebrity endorsements affect consumer choices during new product introductions with planned advertising and unplanned media exposure. It is a person who tells everyone a positive image of the company out of a testimony. This is the strongest and most powerful way of propaganda. A celebrity spokesperson is defined in the advertising industry as any individual widely known by the public who uses this person in advertising to attract consumers to have a good impression of the endorsed product (McCracken, 1989). In the marketing field, companies and brands often use celebrities' popularity and professionalism to gain the attention, and seize the opportunity to deliver strong messages about their products to consumers (Choi \& Rifon, 2007). Bower and Landreth (2001) discussed that through the interactive relationship between spokespersons and products, highly attractive advertising spokespersons often have a more reliable perception in the consumers' eyes, and compared with other types of spokespersons, celebrities' endorsement effect is seen as the most significant. Miciak and Shanklin (1994) discussed that celebrity endorsements can enable consumers to gain immediate awareness of branded products and the use of celebrities to stimulate consumers' knowledge of the product enhances confidence in the product and changes consumer preferences and attitudes. Conversely, a celebrity with a negative image will bring the brand negative image valence. $\mathrm{Yu}$ and $\mathrm{Hu}$ (2020) discussing luxury brands in China found localized (vs. standardized) celebrity endorsements lead to more social media interactions. Using localized (standardized) celebrity endorsements enhance the perceived brand luxury for people with high (low) patriotism.

\subsubsection{Spokesperson Credibility}

The image and credibility of the spokesperson will affect the persuasiveness of the advertisement. A spokesperson with high credibility is more convincing to consumers than one with low credibility (Sternthal, Dholakia \& Leavitt, 1978). When consumers are unfamiliar with advertised products, the role of advertising spokesperson is usually the basis for consumers to judge whether goods or services are credible. Therefore, in addition to the good perceptual quality of the product or service itself, the credibility of the source of information is also an important key factor for consumers' decisions about the product (Ohanian, 1991). Hovland, Janis and Kelley (1953) proposed the Source-Credibility Model stating that the credibility of the source information should include expertness and trustworthiness. Expertness refers to the degree to which consumers are aware of effective information and trustworthiness refers to the degree to which consumers give confidence in the information they hear. Later, McGuire (1985) proposed the Source-Attractiveness Model which stipulated that the effectiveness of a message depends on the attractiveness as the third characteristic of the credible source. Through big data experimental study Ohanian (1990) exploits the aforementioned models exposition to develop and validate a three-dimensional scale to measure the celebrity credibility endorser, including trustworthiness, expertise, and attractiveness. Choi and Rifon (2012) studied the consistency of the image of celebrities and consumers' self-concept from the perspective of consumers, using five dimensions: attractiveness, trustworthiness, expertness, likeability and familiarity.

Using match-up hypothesis, Kamins (1990) suggests that celebrity credibility influences ad and brand evaluations positively if the character of the advertised product matches its endorser's image. With the rising 
tendency of publications in this field, researchers (Bergkvist \& Zhou, 2016) have reviewed the robustness of the relationship between source credibility and various constructs in celebrity endorsement. Interestingly, Schouten, Janssen, and Verspaget (2019) compared celebrity and influencer endorsements in advertising and found that participants identify more with influencers than celebrities, feel more similar to influencers than celebrities, and trust influencers more than celebrities. In terms of advertising effectiveness, similarity, wishful identification, and trust mediate the relationship between type of endorser and advertising effectiveness.

\subsection{Brand Resonance}

\subsubsection{STAYREAL Brand}

STAYREAL is a clothing line jointly founded in 2007 by Mayday's lead singer Ashin and the well-known Taiwanese illustrator Fujin Liang. The name was translated from "STEREO" to "stereo" homophony and the style combines the spirit of the rock music band with innocence, cuteness, humor and realism. The brand originally designed T-shirts as the main merchandise. With the addition of other designers alongside Ashin and Fujin, the team designed sub-clothing lines such as ROCKCOCO (designed by NEWNEW) and CROXXBONES (designed by KEA) which extended the merchandises to various clothing styles and daily necessities such as shirts, jeans, bags, shoes, 3C peripheral products, dolls, etc. In addition, STAYREAL also cooperated with many well-known international brands (including Mercedes-Benz, Coca-Cola, LEVI'S, Timberland, Casio, McDonald's, etc.) to launch joint-branded products. Additionally, the brand created joint designs with well-known cartoon character brands (such as Hello Kitty, SNOOPY, DORAEMON, SpongeBob, Disney, Egg Yolk, Garfield, Pink Panther, etc.).

\subsubsection{Brand Resonance Model}

Keller (2008) proposed the "Brand Resonance Model" derived from his Customer-Based Brand Equity Model proposed in 2001. When the brand reaches the end of the four stages' pyramid, the brand equity will be generated. The four stages of Customer-Based Brand Equity model are: (1) Brand identity is the stage positioning which answers "who you are" in different situations, how often the brand is recalled by consumers, and the degree determines the customer's ability to recognize the brand. (2) Brand meaning refers to what the brand represents, including whether the tangible products and services meet the customer's functional requirements, and intangible services in the brand image association conform to the customer's psychology or social needs. (3) Brand response which indicates how consumers perceive the brand and causes customers to respond appropriately to it. Through the use experience, consumers will judge the brand at different levels such as brand quality, credit and advantage, as well as consumers' responses to the emotions aroused. (4) Brand relationship refers to the relationship between the customer and the brand which mainly transforms the customer's brand response, forms the customer's resonance with the brand, creates a close loyal relationship (Burgess \& Spinks, 2014). The brand resonance pyramid divided into rational and perceptual levels. The left half belongs to the rational level where brand efficacy influences judgment to meet the needs of customers in terms of functional utility. The right half belongs to the perceptual level where brand image will affect perception to meet the psychological and emotional needs of consumers. The combination of these two levels allows consumers to reach a stage of resonance with the brand (Raut, Brito, \& Pawar, 2020). Brand Resonance refers to the characteristics of the relationship between the customer and the brand; and refers to the degree of synchronization between the customer and the brand (Raut et al., 2020). Brand resonance is the last stage of the pyramid. If the customer resonates with the brand, there will be a strong emotional connection with and dependence to the brand which induces loyalty to the brand.

The four factors of Keller's brand resonance model are: (1) Behavioral Loyalty: refers to the customer's loyalty to the brand's specific item consumption and share, which can be measured by the frequency and number of purchases of the brand by consumers. Loyal customers will frequently repeat purchases, patronize various products and services provided by the company, and become immune to other competitive brand promotions (Griffin, 1995). (2) Attitudinal Attachment: refers to the positive attitude of consumers towards the brand and the degree of strong attachment to the brand, which is regarded as a preferred brand. Chaudhuri and Holbrook (2001) believe that when consumers use products or services, they produce positive emotional reactions of satisfaction, which will lead customers to invest more money or resources. With this accumulation of positive emotions, consumers will have an attached feeling with the brand, prompting consumers to maintain a connected relationship with the brand (Thomson, Macinnis \& Park, 2005). (3) Sense of Community: Customers participating in the brand community will have an emotional connection with other customers or employees of the brand; the brand community also provides customers with the brand information, event messages or promotional programs, etc., to establish a brand-customer relationship. The brand community includes real physical communities and virtual communities on the Internet (Keller, 2008). (4) Active Engagement: refers to customers' participation in 
brand-related activities. Customers who are loyal to the brand are willing to invest time, energy, money or other resources on the brand, such as actively browsing the brand website, participating in discussion activities, etc. Mollen and Wilson (2010) believe that customer brand participation is a positive relationship between cognition and emotional commitments. Through online media, it can be divided into online and offline forms of participation. Online participation is the exchange of customer cognition and emotion and offline participation refers to the word-of-mouth evaluation and brand recommendation obtained through the Internet.

\subsection{Hypotheses Development}

Experience has grown into a primary means by which we comprehend of consumer societies in post-industrial. Brands in today's marketplace are required to be relevant, useful, and entertaining. The brand Tesla symbolizes experiential value marked by transcendent enjoyment and create a point of difference. Likewise, Nike Plus offers consumers the opportunity to interact with the brand via workout instructions, health tracking and so forth, even when they are not purchasing a product (Kocheilas, 2018). In a related study, Veloutsou and Guzmán (2017) analyzed the evolution of brand management over the past 25 years and highlighted a key shift: the consumer is no longer a passive purchaser of the brand, but rather demands to be an active participant in creating brand experiences. According to the Gartner report, customers are willing to pay more for a good experience, 89 percent of companies expect to compete on the basis of customer experience compared to 36 percent in 2017 in the new competitive arena of brands (Arora, 2021). A study reveals a full mediation effect of brand credibility between customer brand experiences on brand attitude showing how brand experience shapes brand credibility, leading to favorable brand attitude (Nayeem, Murshed, \& Dwivedi, 2019). Jia and Hu (2019) examined short video brand experience in sensory, emotional, behavioral, and intellectual four perspectives and found that the brand experience has a positive and significant impact on user brand resonance and customer loyalty. To be more specific, brand resonance had partial mediating effect between sensory/ behavioral experience perspectives with customer loyalty. Moreover, brand resonance had fully mediation effect between emotional/intellectual experience perspectives with customer loyalty.

Jhang (2015) study of HTC mobile phone using Mayday as spokesperson on consumers' purchase intention and found that brand image would have mediating affect between spokesperson's credibility and consumers' willingness to purchase products. In the same way, a research explored the PX mart endorsers had positive impact on customer perceived quality, perceived value, and corporate image (Lai, Yu, Chen, Huang, \& Zheng, 2016). With increasing number of celebrities have launched their own businesses, Teng et al. (2020) found customers' perceived congruence between a celebrity and the celebrity's business significantly affects their brand attitudes, and their purchase intentions rely mainly on customers' attitudes toward the celebrity's venture brand.

Till and Busler (1998) pointed out that celebrities with professional knowledge or background are more suitable to endorse products and enhance consumers' attitudes towards brands than celebrities less related to products. Chen and $\mathrm{Wu}$ (2017) tested the influence of the credibility of different spokespersons on brand recognition using respectively internet celebrities, celebrities and typical consumers to endorse the same product. The research results showed that the credibility of the three spokespersons will positively affect consumers brand identity. Through their ideal image, charm and professional knowledge in a certain field, it is easier for consumers to associate celebrities with integrity and trustworthiness. Lin (2006) pointed out that support for idols is transformed into a symbolic consumption. Fans can obtain psychological and physical satisfaction through these consumer behaviors. The consumption experience also leads to the promotion of fans' positive image of idols. For idol-related products or endorsed brand products, therefore it has a multiplier effect. Previous research results pointed out that brand familiarity can improve consumers' perceived value and brand relationship, the relationship between perceived value and brand positively affects consumers' purchase intentions, and the influence of advertising spokespersons can strengthen consumers' perceived value (Wu, Lin, \& Lin, 2015). Based on the above, this paper is trying to add contribution by looking the brand strategy applying the P-O-X theory within three different parties, where $\mathrm{P}$ represents the oneself (audience experience value), $\mathrm{O}$ is the other party (Mayday celebrity endorsement), and $\mathrm{X}$ is a third party between $\mathrm{P}$ and $\mathrm{O}$ (STAYREAL Brand resonance), the following hypotheses are stated:

$\mathrm{H}_{1}$ : Experience value has a significant positive impact on celebrity endorsement.

$\mathrm{H}_{2}$ : Experience value has a significant positive impact on brand resonance.

$\mathrm{H}_{3}$ : Celebrity endorsements have a significant positive impact on brand resonance.

$\mathrm{H}_{4}$ : Celebrity endorsement is a mediating variable between experience value and brand resonance.

\section{Research Method}

This research is based on the balance theory proposed by Heider. The original $\mathrm{P}$ is the Perceiver, $\mathrm{O}$ is the 
Observed, and $\mathrm{X}$ is a third party other than $\mathrm{P}$ and $\mathrm{O}$. In terms of the research structure, the P-O-X theoretical model is extended to take $\mathrm{P}$ as the consumer experience value, $\mathrm{O}$ as the endorsement of celebrities, and $\mathrm{X}$ as the brand resonance, to explore the degree of correlation and balance between the three, the research structure is depicted in Figure 1.

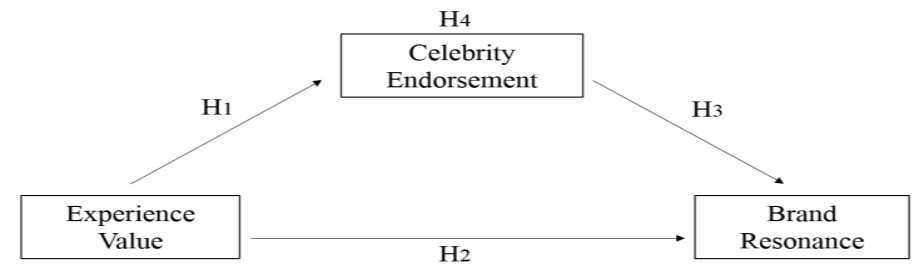

Figure 1. Research model diagram

\subsection{Research Instruments}

All the questionnaires were measured by using a seven-point Likert scale from 1 (strongly disagree) to 7 (strongly agree) with appropriate modifications for this study. The Experience Value (EV) was developed by Sweeney and Soutar (2001) with 13 questions spread between three factors which are function value, emotional value, and social value. The Celebrity Endorsements (CE) refer to the spokesperson credibility and was developed by Ohanian (1990) and Jhang (2015), with 19 questions distributed between five factors which are relevant, attractive, reliable, trustworthiness, and likeable. The Brand Resonance (BR) was developed by Keller (2008), with 13 questions for four factors which were active participation, community, behavioral, and attitude.

\subsection{Research Objects and Sampling Methods}

This study aims to understand the relationship between the consumer experience value in concerts and whether celebrity endorsements will affect consumers' resonance within the brand. Therefore, the research object is mainly fans of the Mayday who ever participated in the Mayday concert. Due to the world tour concert of "Mayday 2018 Life Tour", there was no concert performance in Taiwan. For the accuracy of the research, audience who participate in Mayday related activities the "Super Slippa - part 9" and "The Great Nobody" of 831 were selected. "Super Slippa" is an annual music festival hosted by Mayday's affiliated agency- B'in Music International Co., Ltd. And the 831 is a young rock band under B'in Music International Co., Ltd which held "the Great Nobody". This time Mayday band was invited as a special guest in the concerts performance which would attract same group of fans. Therefore, participants of these two concerts are the subjects of the research. Mall-intercepts method of data collection was used around the concert site at the Taipei Arena in 2018.

\section{Results}

\subsection{Descriptive Statistical Analysis}

The questionnaires were distributed and collected from two concerts in 2018. A total of 469 questionnaires were collected with 236 from the 9th "Super Slippa" music festival on August $4^{\text {th }}$ and $5^{\text {th }}$, and 233 from "The Great Nobody" of 831 rock band on September $1^{\text {st }}$ and $2^{\text {nd }}$. After removing 47 invalid questionnaires that were either $2 / 3$ unfilled or had the item "I never participated the Mayday concert" ticked, 422 valid questionnaires remained. Most of the respondents were female (83.4\%), aged between 30-39 years old (37.9\%), followed by 25-29 years old $(29.4 \%)$. The majority of respondents hold a college degree $(73.5 \%)$ with an average monthly income of NT $\$ 10,001-30,000(30.6 \%)$ followed by NT\$30,001-40,000 (28.4\%). Most respondents have participated in concerts more than 11 times (36.7\%) followed by 3-5 times (23.5\%), 1-2 times (20.1\%), and 6-10 times (19.7\%); most of them received concert information from the social community or official website (64.5\%), followed by recommendations from relatives and friends (25\%). Approximately $91.2 \%$ respondents have purchased the merchandise of concert clothes, CDs, towels and stickers with consumption amount around NT\$1,001-2,000 (23.2\%). In addition, respondents owning STAYREAL products accounted for about $82.2 \%$; and the number of people who had purchased STAYREAL products at the concert accounted for 53.1\%; most of their purchases of STAYREAL were T-SHIRT, bags, and outerwear with consumption amount around NT\$1,001-2,000 (29.1\%).

\subsection{Validity and Reliability}

Exploratory factor analysis (EFA) using the principal components analysis procedure was performed to determine the factor structure of all research constructs. To determine the factorability of the data, a Kaiser-Meyer-Olkin (KMO) measure of sampling adequacy and Bartlett's test of sphericity were computed. The minimum cut-off KMO value is 0.5 and with Bartlett's test significant, thereby signaling the factorability of the data (Bartlett 1951; Kaiser 1970). Only factors with eigenvalues greater than 1 and items' factor loadings higher 
than 0.5 were retained, in line with the seminal recommendation by Kaiser (1960). In terms of the cumulative percentage of variance explained, it's better exceeded the recommended minimum of $60 \%$ (Hair, Black, Babin \& Anderson, 2019). Construct validity was tested using factor loadings derived in the EFA procedure which recommended lowest cut-off value of 0.5 by Kang (2013). Reliability of the consistency of research measurements was tested using the Cronbach's alpha coefficient which refers to the degree of measurements are free from errors and therefore yield consistent results (Ang, 2014). Tavakol and Dennick (2011) mentioned that $\alpha$ was intended to provide an internal consistency measurement and is expressed as a number between 0 and 1 , with the minimum recommended threshold of 0.7 (DeVellis, 2012).

\subsubsection{Experience Value}

Exploratory factor analysis shown results of the $\mathrm{KMO}$ value is $0.893>0.5$, and the $\chi^{2}$ value of Bartlett's sphere test is 3301.769 significant ( $\mathrm{p}<.001$ ) indicating that it is suitable for factor analysis. Item 7 (I want to participate the concert again) double loaded on both factors, therefore it was deleted and the data re-analyzed. The results shown in Table 1 indicated that three factors were underlying the experience value, namely "functional value" with $35.09 \%$ variance explained, "emotional value" with $24.67 \%$ variance explained, and "social value" $14.18 \%$ variance explained. The overall cumulative variance explained is $73.94 \%$ which indicated the scale has high construct validity. After factor analysis, Cronbach's $\alpha$ reliability analysis is performed, and the factors in functional, emotional and social values have $\alpha$ values of respectively $0.90,0.74$ and 0.86 . Additionally, $\alpha$ value of the experience value is 0.87 . All $\alpha$ values are all greater than 0.7 indicating that this scale has a high degree of reliability.

Table 1. Experience value factor analysis and reliability

\begin{tabular}{|c|c|c|c|c|}
\hline Factor & e & $\begin{array}{l}\text { Factor } \\
\text { loading }\end{array}$ & $\begin{array}{c}\text { Variance } \\
\text { explained \% }\end{array}$ & $\alpha$ value \\
\hline \multirow{6}{*}{$\begin{array}{l}\text { Functional } \\
\text { Value }\end{array}$} & 2. I am satisfied with the arrangement of the concert content & 0.854 & \multirow{6}{*}{35.09} & \multirow{6}{*}{0.90} \\
\hline & $\begin{array}{l}\text { 3. I am satisfied with the sound and light effect of the concert stage } \\
\text { design }\end{array}$ & 0.820 & & \\
\hline & 1. The overall performance of the concert has good quality & 0.813 & & \\
\hline & 6. I think the concert is worth the price & 0.808 & & \\
\hline & 4. The concert will leave me with good memories & 0.786 & & \\
\hline & 5. The ticket price for the concert is reasonable & 0.660 & & \\
\hline \multirow{2}{*}{$\begin{array}{l}\text { Emotional } \\
\text { Value }\end{array}$} & 8. The concert makes me feel quite relaxed. & 0.775 & \multirow{2}{*}{24.67} & \multirow{2}{*}{0.74} \\
\hline & 9. The concert brings me joy. & 0.768 & & \\
\hline \multirow{4}{*}{$\begin{array}{l}\text { Social } \\
\text { Value }\end{array}$} & 11. The concert can make me meet new friends. & 0.849 & \multirow{4}{*}{14.18} & \multirow{4}{*}{0.86} \\
\hline & 12. The concert makes others leave a good impression on me. & 0.842 & & \\
\hline & 10. The concert increased my interaction with others. & 0.834 & & \\
\hline & 13. The concert can make Mayday get social approval. & 0.774 & & \\
\hline \multicolumn{3}{|c|}{ Experience value cumulative Variance explained (\%) } & \multicolumn{2}{|c|}{73.94} \\
\hline \multicolumn{3}{|c|}{ Experience value Cronbach's $\alpha$ value } & \multicolumn{2}{|c|}{0.87} \\
\hline
\end{tabular}

Note. Factor loadings $<0.5$ are suppressed.

\subsubsection{Celebrity Endorsements}

Exploratory factor analysis shown results of the KMO value of celebrity endorsements is $0.918>0.5$, and the $\chi^{2}$ value of Bartlett's sphere test is 4398.86 significant $(\mathrm{p}<.001)$, which means it is suitable for factor analysis. Item 10 (I rarely hear negative news about Mayday) was deleted due to small loading (less than 0.40). Item 8 (I think the ads endorsed by Mayday are trustworthy) double loaded on both factors, so it was removed and re-analyze. The results are shown in Table 2, four factors were underlying the celebrity endorsements, which are "relevant", "attractive", "reliable", and "likeable"; the overall cumulative variance explained celebrity endorsements was $75.21 \%$ which indicated the scale has high construct validity. After factor analysis, Cronbach's $\alpha$ reliability analysis was performed on each facet of celebrity endorsements, the relevant $\alpha$ value was 0.90 , the attractive $\alpha$ value was 0.84 , the reliable $\alpha$ value was 0.85 , the likeable $\alpha$ value was 0.89 , and the overall $\alpha$ value of the celebrity endorsement scale is 0.93 . All $\alpha$ value greater than 0.7 indicating that this scale has a high degree of reliability. 
Table 2. Celebrity endorsement factor analysis and reliability

\begin{tabular}{|c|c|c|c|c|}
\hline Factor & items & $\begin{array}{l}\text { Factor } \\
\text { loading }\end{array}$ & $\begin{array}{c}\text { Variance } \\
\text { explained \% }\end{array}$ & $\begin{array}{c}\alpha \\
\text { value }\end{array}$ \\
\hline \multirow{4}{*}{ Relevant } & 12. I think Mayday is related to STAYREAL products. & 0.870 & \multirow{4}{*}{22.49} & \multirow{4}{*}{0.90} \\
\hline & $\begin{array}{l}\text { 14. I think it is appropriate for Mayday to endorse STAYREAL } \\
\text { products. }\end{array}$ & 0.842 & & \\
\hline & $\begin{array}{l}\text { 13. I think the brand image of Mayday and STAYREAL have } \\
\text { similar characteristics. }\end{array}$ & 0.831 & & \\
\hline & $\begin{array}{l}\text { 7. I think Mayday endorsement of the STAYREAL brand is } \\
\text { professional. }\end{array}$ & 0.743 & & \\
\hline \multirow{4}{*}{ Attractive } & $\begin{array}{l}\text { 4. I think Mayday's outstanding performance in acting has } \\
\text { affected my identification with him. }\end{array}$ & 0.739 & \multirow{4}{*}{18.35} & \multirow{4}{*}{0.84} \\
\hline & 3. I like the youthful vitality shown by Mayday. & 0.721 & & \\
\hline & 2. When Mayday appears, it often attracts my attention. & 0.702 & & \\
\hline & 1. I think Mayday is very attractive. & 0.686 & & \\
\hline \multirow{4}{*}{ Reliable } & $\begin{array}{l}\text { 6. As far as Mayday's overall performance is concerned, I thinl } \\
\text { are professional advertising spokespersons. }\end{array}$ & 0.816 & \multirow{4}{*}{17.81} & \multirow{4}{*}{0.85} \\
\hline & $\begin{array}{l}\text { 5. I think Mayday has served as a spokesperson for multiple } \\
\text { advertisements and is very experienced. }\end{array}$ & 0.777 & & \\
\hline & 9. I think the image of Mayday is honest and reliable. & 0.583 & & \\
\hline & $\begin{array}{l}\text { 11. I think Mayday's endorsement will enhance the brand } \\
\text { image. }\end{array}$ & 0.530 & & \\
\hline \multirow{3}{*}{ Likeable } & 16. I think Mayday's endorsements are friendly. & 0.764 & \multirow{3}{*}{16.55} & \multirow{3}{*}{0.89} \\
\hline & 15. I think Mayday's endorsements are pleasant. & 0.743 & & \\
\hline & 17. I think Mayday's endorsements are my favorite. & 0.677 & & \\
\hline \multicolumn{3}{|c|}{ Celebrity endorsement cumulative Variance explained (\%) } & \multicolumn{2}{|c|}{75.21} \\
\hline \multicolumn{3}{|c|}{ Celebrity endorsement Cronbach's $\alpha$ value } & \multicolumn{2}{|c|}{0.93} \\
\hline
\end{tabular}

Note. Factor loadings $<0.5$ are suppressed.

\subsubsection{Brand Resonance}

Exploratory factor analysis shown results of the KMO value of Brand Resonance is $0.951>0.5$, and the $\chi 2$ value of Bartlett spherical test is 6468.78 significant $(\mathrm{p}<.001)$, indicating that it is suitable for factor analysis. Item 4 (I really like the STAYREAL brand) double loaded on both factors, so it was removed and re-analyze. The results extracted four factors "active engagement", "community", "behavioral", and "attitude"; the overall cumulative explained variation is $90.12 \%$ which indicated the brand resonance scale has high construct validity. After factor analysis, Cronbach's $\alpha$ reliability analysis was performed, the active participation $\alpha$ was 0.96 , the community Cronbach's $\alpha$ was 0.93 , the attitude dependence $\alpha$ was 0.91 , and the behavior $\alpha$ was 0.93 , and the overall brand resonance scale is 0.97 . All $\alpha$ value greater than 0.7 indicating that this scale has a high degree of reliability.

Table 3. Brand resonance factor analysis and reliability

\begin{tabular}{|c|c|c|c|c|}
\hline Factor & items & $\begin{array}{l}\text { Factor } \\
\text { loading }\end{array}$ & $\begin{array}{c}\text { Variance } \\
\text { explained \% }\end{array}$ & $\alpha$ value \\
\hline \multirow{4}{*}{ Active engagement } & $\begin{array}{l}\text { 11. I am very interested to learn more about the STAYREAL } \\
\text { brand. }\end{array}$ & 0.784 & \multirow{4}{*}{28.27} & \multirow{4}{*}{0.96} \\
\hline & 10. I am happy to tell others about the STAYREAL brand. & 0.746 & & \\
\hline & $\begin{array}{l}\text { 12. I am very interested in the products endorsed by the } \\
\text { STAYREAL brand. }\end{array}$ & 0.742 & & \\
\hline & 13. I like to browse the STAYREAL brand website. & 0.729 & & \\
\hline \multirow{3}{*}{ Community } & $\begin{array}{l}\text { 8. I feel that the people who use the STAYREAL brand } \\
\text { belong to the same social group as me. }\end{array}$ & 0.821 & \multirow{3}{*}{24.55} & \multirow{3}{*}{0.93} \\
\hline & $\begin{array}{l}\text { 9. I feel that I have a common affinity with people who use } \\
\text { the STAYREAL brand. }\end{array}$ & 0.815 & & \\
\hline & 7. I identify with people who use the STAYREAL brand. & 0.706 & & \\
\hline \multirow{3}{*}{ Behavior } & $\begin{array}{l}\text { 2. Even if there are other new brands of clothing, I will still } \\
\text { insist on buying the STAYREAL brand. }\end{array}$ & 0.775 & \multirow{3}{*}{24.04} & \multirow{3}{*}{0.93} \\
\hline & 1. If I buy again, I will still choose the STAYREAL brand. & 0.767 & & \\
\hline & $\begin{array}{l}\text { 3. Even if the brand does not advertise, I will still buy the } \\
\text { STAYREAL brand. }\end{array}$ & 0.735 & & \\
\hline \multirow[b]{2}{*}{ Attitude } & 6. The STAYREAL is not just a product brand to me. & 0.759 & \multirow[b]{2}{*}{13.25} & \multirow[b]{2}{*}{0.91} \\
\hline & 5. The STAYREAL brand is very special to me. & 0.578 & & \\
\hline \multicolumn{3}{|c|}{ Brand resonance cumulative Variance explained (\%) } & \multicolumn{2}{|c|}{90.12} \\
\hline \multicolumn{3}{|c|}{ Brand resonance Cronbach's $\alpha$ value } & \multicolumn{2}{|c|}{0.97} \\
\hline
\end{tabular}

Note. Factor loadings $<0.5$ are suppressed. 
As shown in Table 4, at significance level $\mathrm{p}<.01$ (two-tailed) the EV have positive linear relationships among $\mathrm{CE}, \mathrm{BR}$ and their factors with correlation coefficient $r$ taking values between 0.45 and 0.84 . The correlation between $\mathrm{EV}$ and $\mathrm{CE}$ is 0.72 ( $\mathrm{p}<.01)$ means the higher the experience value that consumers perceived in the concert, the more they endorse the celebrity and with higher degree of recognition. Also, a moderate positive correlation was found between EV and BR $(r=0.56)$ indicating that the higher the value in functional $(\mathrm{r}=0.51)$, emotional $(\mathrm{r}=0.48)$, and social $(\mathrm{r}=0.55)$ experience that consumers obtain from the concert, the higher the degree of resonance with the brand. The correlation between CE and BR is $0.65(\mathrm{p}<.01)$, showing that the higher the degree of recognition in relevant, attractive, reliable and likeable of celebrity, their active participation, sense of community, attitude, and behavior of the brand resonance and is relatively higher.

Table 4. Means, Standard Deviations and Correlations among Variables

\begin{tabular}{|c|c|c|c|c|c|c|c|c|c|c|c|c|c|c|c|}
\hline Variables & Mean & SD & 1 & $1 \mathrm{a}$ & $1 \mathrm{~b}$ & $1 \mathrm{c}$ & 2 & $2 a$ & $2 b$ & $2 c$ & $2 \mathrm{~d}$ & 3 & $3 \mathrm{a}$ & $3 b$ & $3 c$ \\
\hline 1. $\mathrm{EV}$ & 6.41 & .61 & 1 & & & & & & & & & & & & \\
\hline 1a. Functional & 6.65 & .57 & $.82^{* *}$ & 1 & & & & & & & & & & & \\
\hline 1b. Emotional & 6.70 & .69 & $.67^{* *}$ & $.67^{* *}$ & 1 & & & & & & & & & & \\
\hline 1c. Social & 5.91 & 1.07 & $.82^{* *}$ & $.37^{* *}$ & $.27^{* *}$ & 1 & & & & & & & & & \\
\hline 2. $\mathrm{CE}$ & 6.45 & .65 & $.72^{* *}$ & $.62^{* *}$ & $.51^{* *}$ & $.56^{* *}$ & 1 & & & & & & & & \\
\hline 2a. Relevant & 6.13 & 1.04 & $.45^{* *}$ & $.30^{* *}$ & $.25^{* *}$ & $.44^{* *}$ & $.84^{* *}$ & 1 & & & & & & & \\
\hline 2b. Attractive & 6.62 & .64 & $.69^{* *}$ & $.68^{* *}$ & $.58^{* *}$ & $.44^{* *}$ & $.81^{* *}$ & $.47^{* *}$ & 1 & & & & & & \\
\hline 2c. Reliable & 6.49 & .67 & $.71^{* *}$ & $.61^{* *}$ & $.48^{* *}$ & $.56^{* *}$ & $.87^{* *}$ & $.59^{* * *}$ & $.69^{* *}$ & 1 & & & & & \\
\hline 2d. Likable & 6.58 & .71 & $.68^{* *}$ & $.67^{* *}$ & $.52^{* *}$ & $.45^{* *}$ & $.85^{* *}$ & $.55^{* *}$ & $.73^{* *}$ & $.73^{* *}$ & 1 & & & & \\
\hline $\begin{array}{ll}3 . & \mathrm{BR} \\
\end{array}$ & 5.72 & 1.20 & $.56^{* *}$ & $.42^{* *}$ & $.28^{* *}$ & $.52^{* *}$ & $.65^{* *}$ & $.60^{* *}$ & $.51^{* *}$ & $.56^{* *}$ & $.49^{* *}$ & 1 & & & \\
\hline 3a. Active & 5.85 & 1.24 & $.51^{* *}$ & $.37^{* *}$ & $.25^{* *}$ & $.48^{* * *}$ & $.58^{* *}$ & $.54^{* *}$ & $.43^{* *}$ & $.50^{* * *}$ & $.44^{* *}$ & $.95^{* *}$ & 1 & & \\
\hline 3b. Community & 5.56 & 1.34 & $.48^{* *}$ & $.32^{* *}$ & $.22^{* *}$ & $.48^{* *}$ & $.60^{* *}$ & $.56^{* *}$ & $.48^{* *}$ & $.49^{* * *}$ & $.43^{* *}$ & $.91^{* * *}$ & $.80^{* *}$ & 1 & \\
\hline 3c. Behavior & 5.66 & 1.33 & $.55^{* *}$ & $.47^{* *}$ & $.30^{* *}$ & $.46^{* *}$ & $.65^{* *}$ & $.60^{* *}$ & $.50^{* *}$ & $.56^{* *}$ & $.51^{* *}$ & $.92^{* * *}$ & $.83^{* *}$ & $.76^{* *}$ & 1 \\
\hline 3d. Attitude & 5.80 & 1.26 & $.54^{* *}$ & $.42^{* *}$ & $.25^{* *}$ & $.50^{* *}$ & $.60^{* *}$ & $.53^{* *}$ & $.48^{* *}$ & $.53^{* *}$ & $.46^{* *}$ & $.92^{* * *}$ & $.85^{* *}$ & $.80^{* *}$ & $.82^{* *}$ \\
\hline
\end{tabular}

Note. Listwise excluded, ${ }^{* *} p<.01$, two- tailed. 1. EV - Experience Value, 2. CE - Celebrity Endorsement, 3. BR - Brand Resonance.

\subsection{Regression Analysis}

Multiple regression analyses were conducted to examine research hypotheses one to four, the linear relationship between experience value, celebrity endorsements and brand resonance. Baron and Kenny (1986) discussed that multi-regression procedure for mediation was used to examine mediation effect. The procedure involves estimating four separate regression equations. First the independent variable (Experience Value - EV) should be significantly related to the mediator (Celebrity Endorsement - CE). Second, the independent variable (EV) should be significantly related to the dependent variable (Brand Resonance - BR); third the mediating variable (CE) should be significantly related to the dependent variable (BR). And lastly, the mediating variable (CE) should be significantly related to the dependent variable (BR) with the independent variable (EV) included in the equation. If all conditions hold, beta weight drops between independent and dependent variables, partial mediation is deemed present. If the independent variable has non-significant beta weights in the final step, then complete mediation is present.

The results for the mediation effect of $\mathrm{CE}$ are shown in Table 5, the first equation (EV on CE) is significant $[\mathrm{F}(420)=456.72, \beta=.72, \mathrm{p}<.001]$. So is the second equation $(\mathrm{EV}$ on $\mathrm{BR})[\mathrm{F}(420)=189.88, \beta=.56, \mathrm{p}<.001]$, and the third equation ( $\mathrm{CE}$ on $\mathrm{BR})$ as well $[\mathrm{F}(420)=312.39, \beta=.65, \mathrm{p}<.001]$. In the last equation the dependent variable $(\mathrm{BR})$ was regressed on the mediating variable $(\mathrm{CE})$ with the independent variable $(\mathrm{EV})$ where a significant impact is seen $\left[\mathrm{F}(419)=166.08, \beta_{\mathrm{EV}}=.18, \beta_{\mathrm{CE}}=.52, \mathrm{p}<.001\right]$. Since all equations were significant and the beta weight dropped $\left(\beta_{\mathrm{EV}}=.56 \rightarrow .18\right)$, partial mediation is present which indicates that when "celebrity endorsement" is added, the explanatory power between EV and BR decreases, thus confirming that experience value has an impact on brand resonance through the mediation effect of celebrity endorsement. Therefore, research hypotheses one to four were all supported. Hypotheses 1 and 2: Experience value has a significant positive impact on celebrity endorsements and brand resonance. Hypothesis 3: Celebrity endorsements have a significant positive impact on brand resonance. Hypothesis 4: Celebrity endorsement is a mediating variable between experience value and brand resonance. 
Table 5. Regression analysis for mediation effect of Celebrity Endorsement

\begin{tabular}{cccccccc}
\hline Equation & Ind. V. & Dep. V. & df & F & Adj. $\mathrm{R}^{2}$ & $t$ & $\beta$ \\
\hline 1 & EV & CE & 420 & $456.72^{* * *}$ & .52 & $21.37^{* * *}$ & .77 \\
\hline 2 & EV & BR & 420 & $189.88^{* * *}$ & .31 & $13.78^{* * * *}$ & .56 \\
\hline 3 & CE & BR & 420 & $312.39^{* * *}$ & .43 & $17.68^{* * *}$ & .65 \\
\hline 4 & EV & BR & 419 & $166.08^{* * * *}$ & .44 & $3.43^{* * * *}$ & .18 \\
& CE & & & & & $9.91^{* * *}$ & .52 \\
\hline
\end{tabular}

Note. ${ }^{* *} \mathrm{p}<.01,{ }^{* * *} \mathrm{p}<.001$, standardized $\beta$ reported. EV - Experience Value; CE - Celebrity Endorsement; BR Brand Resonance

\section{Conclusion}

\subsection{Research Results}

Our research base on the application of the P-O-X theory explored relationships between consumer experience value, Mayday celebrity endorsements and STAYREAL brand resonance. The results show that 1 . Experience value has a significant positive impact on celebrity endorsements; 2 . Experience value has a significant positive impact on brand resonance. 3. Celebrity endorsements have a significant positive impact on brand resonance; and 4. Celebrity endorsements have a partial mediating effect between experience value and brand resonance, which proves that $\mathrm{P}-\mathrm{O}-\mathrm{X}$ is in a balanced state. Results are similarly with previous researches, such as Nayeem, et al. (2019) brand credibility has mediation effect between customer brand experience on brand attitude showing how brand experience shapes brand credibility, leading to favorable brand attitude; Jia and Hu's (2019) the brand experience has a significant positive impact on user brand resonance and customer loyalty; Teng, et al. (2020) found customers' perceived congruence between a celebrity and the celebrity's business significantly affects their brand attitudes, and their purchase intentions rely mainly on customers' attitudes toward the celebrity's venture brand; fans support a celebrity directly with their consumption activities such as attending a concert, watching a movie, and buying mementos (Jia, et al., 2017); and Wu, et al. (2015) suggested brand familiarity can improve consumers' perceived value and brand relationship and the advertising spokespersons can strengthen consumers' perceived value. Our results are not identical with previous research since our research construct are from three different parties. Although the results are not duplicate previous research with same constructs, the idea of the experience value, celebrity endorsement, and brand resonance/attitude meaning are identical. Compare to other studies, this study brings more contribution and interesting results by applying the P-O-X theory within three parties, where $\mathrm{P}$ represents the oneself (Experience value), $\mathrm{O}$ is the other party (Mayday celebrity endorsement), and $\mathrm{X}$ is a third party between $\mathrm{P}$ and O (STAYREAL Brand resonance). This research found celebrity endorsements have a partial mediation effect between experience value and brand resonance, which means that the degree of consumer experience value for brand resonance will be affected by celebrity endorsements, but not entirely influenced by celebrities, it may influence consumers through other factors. In previous literature review of Keller's (2008) brand resonance pyramid it presents left half belongs to the utility function of brand efficacy and right half affect perception to meet consumers' psychological needs. The combination of utility and emotional functions allows consumers to reach a stage of resonance with the brand (Raut et al., 2020). Therefore, to see a whole frame of brand resonance, future research can examine the utility factors such as brand attributes in price, design, fabric, comfort, color, etc. at the same time.

\subsection{Management Implications}

5.2.1 Fascinate New Audience and Enhance the Concert Experience Consumption which would Expand STAYREAL Brand Awareness Also Increase Market Coverage

In live concert while audience adore and appraise the stage, sound, light design, repertoire arrangement to singer performance, etc., they created experience value from their heart which triggers physical and mental satisfaction during the consumption process. This study found that the great consumption experience in the concert will impact consumers' celebrity image shaping and promote attraction and continuous support for celebrity endorsements. It also found that audience would sustain the brand resonance with positive attitude in celebrity endorsements and sufficient experience value in concert. Respondents demographic data show there were few people participated the concert first or second time, indicating that there are still numerous potential customers can join or occasionally participated the concert and having chance to become a loyalty fan. In addition, since most respondent received the Mayday information from social and official website, follow by word-of-mouth recommend from family and friends, we suggest Mayday marketing manager post more message in social/official website and continue to hold 
the fan meeting since those loyalty fans maybe the key opinion leaders who distribute news on their own social media that make more people knowing Mayday. For the STAYREAL brand, we suggest of giving sales promotion to the potential audience and the loyalty fan who have concert ticket. By wearing STAYREAL brand costumes at the concert would increase brand awareness, become a symbol while attend Mayday concert, attract other customers' attention, as to enhance the connection between celebrities and brands, and expand the brand market share.

5.2.2 Strengthen the Connection between the Spokesperson and the Brand, Highlight the Uniqueness of the Brand

In brand marketing, celebrity endorsement is the fastest way to attract attention and convey the brand message to consumers. This research confirms that celebrity endorsements will positively affect the degree of brand resonance. The charm of Mayday's performance on stage telling the life stories of diverse generations is conveying the persistent spirit of love and the pursuit of dreams through rock and lyrical music which connected the band and fans. Mayday's lead singer Ashin is a co-founder and also spokesperson to STAYREAL, to use the Mayday's celebrity reputation with audience concert experience value, we suggested that Mayday band members should all become STAYREAL spokespersons and exposure the brand costumes in concert stage inadvertently. In addition, we recommended to sell Mayday concert costumes in STAYREAL categories, these would help Mayday fans recognizing the brand effortlessly. Currently, STAYREAL categories including T-shirt, hoodies, sweatshirt, jacket, shirt and pants, and well-known cartoon character, with per se suggestions would help strengthen Mayday band members, fans, and STAYREAL brand interactive connection. This would highlight the brand style and the image of the consistency of the spokesperson, so that consumers can empathize with the brand and give the special meaning and value of the product.

\subsubsection{Manage STAYREAL by Using the Brand Resonance Pyramid Model}

In order to establish a high degree of connection between the brand and customers, brand resonance is the highest-level goal of brand development. To achieve the brand resonance stage, customers must have a good perception of the brand and products. It is recommended that brand manager follow the pyramid stage and let customers can evoke brand products in different contexts, and remember product effects and usage images, and generate perceptual value for the brand, which in turn enables customers to have a solid psychological attachment to the brand and loyal consumption behavior to achieve brand resonance. At the end, consumers will enthusiastic to promote the STAYREAL brand to others, and are interested in the brand's products while identify themselves in a sense of community.

\section{References}

Ang, S. H. (2014). Research design for business \& management. London, England: Sage Publication. https://doi.org/10.4135/9781473909694

Baron, R. M., \& Kenny, D. A. (1986). The moderator-mediator variable distinction in social psychological research: Conceptual, strategic and statistical considerations. Journal of Personality and Social Psychology, 51, 1173-1182. https://doi.org/10.1037/0022-3514.51.6.1173

Bartlett, M. S. (1951). The effect of standardization on a $\chi^{2}$ approximation in factor analysis. Biometrika, 38(3/4), 337-344. https://doi.org/10.1093/biomet/38.3-4.337

Bergkvist, L., \& Zhou, K. Q. (2016). Celebrity endorsements: A literature review and research agenda. International Journal of Advertising, 35(4), 642-663. https://doi.org/10.1080/02650487.2015.1137537

Bower, A. B., \& Landreth, S. (2001). Is beauty best? Highly versus normally attractive models in advertising. Journal of Advertising, 30(1), 1-12. https://doi.org/10.1080/00913367.2001.10673627

Burgess, J., \& Spinks, W. (2014). An examination of the four factors of brand resonance and their theoretical application to video games. Journal of New Business Ideas \& Trends, 12(2), 37-49. Retrieved from https://research.usc.edu.au/discovery/fulldisplay/alma99449039402621/61USC_INST:ResearchRepository

Chaudhuri, A., \& Holbrook, M. B. (2001). The chain of effects from brand trust and brand affect to brand performance: The role of brand royalty. Journal of Marketing, 65(2), 81-93. https://doi.org/10.1509\%2Fjmkg.65.2.81.18255

Chen, Y. Y., \& Wu, H. J. (2017). The impacts of spokesperson's credibility on the consumer's brand identity. Management Information Computing, 6(1), 93-103. http://dx.doi.org/10.6285\%2fMIC.6(S1).09

Choi, S. M., \& Rifon, N. J. (2007). Who is the celerity in advertising? Understanding dimensions of celebrity images. The Journal of Popular Culture, 40(2), 304-324. https://doi.org/10.1111/j.1540-5931.2007.00380.x 
Choi, S. M., \& Rifon, N. J. (2012). It is a match: The impact of congruence between celebrity image and consumer ideal self on endorsement effectiveness. Psychology and Marketing, 29(9), 639-650. https://doi.org/10.1002/mar.20550

Cohen, J. B., \& Areni, C. S. (1991). Affect and consumer behavior. In T. S. Robertson \& H. H. Kassarjian (Eds.), Handbook of Consumer Behavior (pp.188-240). Englewood Cliffs, NJ: Prentice-Hall.

Derdenger, T. P., Li, H., \& Srinivasan, K. (2018). Firms' strategic leverage of unplanned exposure and planned advertising: An analysis in the context of celebrity endorsements. Journal of Marketing Research, 55(1), 14-34. https://doi.org/10.1509\%2Fjmr.16.0260

DeVellis, R. F. (2012). Scale development: Theory and applications. Los Angeles, CA: Sage.

Elberse, A., \& Verleun, J. (2012). The economic value of celebrity endorsements. Journal of Advertising Research, 52(2), 149-165. https://doi.org/10.2501/JAR-52-2-149-165

Freiden, J. B. (1984). Advertising spokesperson effects: An examination of endorser type and gender on two audiences. Journal of Advertising Research, 24(5), 33-41.

Gilal, F. G., Paul, J., Gilal, N. G., \& Gilal, R. G. (2020). Celebrity endorsement and brand passion among air travelers: Theory and evidence. International Journal of Hospitality Management, 85, 102347. https://doi.org/10.1016/j.ijhm.2019.102347

Griffin, J. (1995). Customer loyalty: How to earn it and how to keep it. New York, NY: Lexington Books.

Hair, J. F. Jr., Black, W. C., Babin, B. I., \& Anderson, R. E. (2019). Multivariate data analysis. Asia, Cengage.

Han, J., Seo, Y., \& Ko, E. (2017). Staging luxury experiences for understanding sustainable fashion consumption: A balance theory application. Journal of Business Research, 74, 162-167. https://doi.org/10.1016/j.jbusres.2016.10.029

Heider, F. (1958). The psychology of interpersonal relations. New York, NY: John Wiley and Sons. https://doi.org/10.1037/10628-000

Helkkula, A., Kelleher, C., \& Pihlström, M. (2012). Characterizing value as an experience: Implications for service researchers and managers. Journal of Service Research, 15(1), 59-75. https://doi.org/10.1177/1094670511426897

Ho, W. H. (2013). Influence of consumer, K-pop singer and destination image based on balance model (Master thesis, National Chung Cheng University, Chiayi, Taiwan). https://hdl.handle.net/11296/a2m79q

Holbrook, M. B. (1986). Aims, concepts, and methods for the representation of individual differences in esthetic responses to design features. Journal of Consumer Research, 13(3), 337-347. https://doi.org/10.1086/209073

Holbrook, M. B. (1999). Consumer value: A framework for analysis and research. London, England: Psychology Press.

Holbrook, M. B., \& Hirschman, E. C. (1982). The experiential aspects of consumption: Consumer fantasies, feelings, and fun. Journal of Consumer Research, 9(2), 132-140. https://doi.org/10.1086/208906

Hovland, C. I., Janis, I. L., \& Kelley, H. H. (1953). Communication and persuasion: Psychological studies of opinion change. New Haven: Yale University Press.

Jhang, W. C. (2015). To discuss the relationship between celebrity credibility, brand image and purchase intentions: Using Mayday endorsement HTC as an example (Master thesis, Shih Chien University, Taipei, Taiwan). Retrieved from https://hdl.handle.net/11296/s3abxj

Jia, M. M., \& Hu, W. S. (2019). An empirical study on the influence of brand experience and brand resonance on customer loyalty with respect to short clips APP. Journal of Qiqihar University (Philosophy and Social Sciences Edition), 5, 73-77.

Jia, X., Hung, K., \& Zhang, K. (2017). Diversity of fans on social media: The case of entertainment celebrity in China. In C. L. Wang, (Ed.), Exploring the rise of fandom in contemporary consumer culture (Ch.9, pp. 163-184). Hershey, PA: IGI Global. https://doi.org/10.4018/978-1-5225-3220-0.ch009

Kaiser, H. F. (1960). The application of electronic computers to factor analysis. Educational \& Psychological Measurement, 20(1), 141-151. https://doi.org/10.1177/001316446002000116

Kaiser, H. F. (1970). A second generation little jiffy. Psychometrika, 35(4), 401-415. 
https://doi.org/10.1007/BF02291817

Kaltcheva, V. D., \& Weitz, B. A. (2006). When should a retailer create an exciting store environment? Journal of Marketing, 70(1), 107-118. https://doi.org/10.1509/jmkg.70.1.107.qxd

Kamins, M. A. (1990). An investigation into the "match-up" hypothesis in celebrity advertising: When beauty may be only skin deep. Journal of Advertising, 19, 4-13. https://doi.org/10.1080/00913367.1990.10673175

Kang, H. (2013). A guide on the use of factor analysis in the assessment of construct validity. Journal of Korean Academic Nursing, 43(5), 587-594. https://doi.org/10.4040/jkan.2013.43.5.587

Keller, K. L. (2008). Strategic brand management: Building, measuring, and managing brand equity. Upper Saddle River, NJ: Prentice Hall.

Kocheilas, A. (2018). The ways customers use products have changed - but brands haven't kept up. Harvard Business Review Digital Article. Retrieved from

https://hbr.org/2018/05/the-ways-customers-use-products-have-changed-but-brands-havent-kept-up

Kwortnik, R. J. Jr., \& Ross, W. T. Jr. (2007). The role of positive emotions in experiential decisions. International Journal of Research in Marketing, 24(4), 324-335. https://doi.org/10.1016/j.ijresmar.2007.09.002

Lai, L. H., Yu, Y. C., Chen, S. J., Huang, P. R., \& Zheng, H. Y. (2016). The relationship between endorsers and consumer purchase intentions - The example of PX Mart. Ling Tung Journal, 39, 49-74.

Laroche, M., Bergeron, J., \& Barbaro-Forleo, G. (2001). Targeting consumers who are willing to pay more for environmentally friendly products. Journal of Consumer Marketing, 18(6), 503-520. https://doi.org/10.1108/EUM0000000006155

Lin, F. M. (2006). When newsmen become critics: Inquiry of fame, profession, and labor commodification. Mass Communication Research, 88, 43-81. http://dx.doi.org/10.30386\%2fMCR.200607_(88).0002

Mathwick, C., Malhotra, N. K., \& Rigdon, E. (2002). The effect of dynamic retail experiences on experiential perceptions of value: An internet and catalog comparison. Journal of Retailing, 78(1), 51-60. https://doi.org/10.1016/S0022-4359(01)00066-5

McCracken, G. (1989). Who is the celebrity endorser? Cultural foundation of the endorsement process. Journal of Consumer Research, 16, 310-321. https://doi.org/10.1086/209217

McGuire, W. J. (1985). Attitudes and attitude change. In G. Lindzey \& E. Aronson (Eds.), Handbook of social psychology (Vol. 2, pp.233-346). New York, NY: Random House.

Miciak, A. R., \& Shanklin, W. L. (1994). Choosing celebrity endorsers. Marketing Management, 3(3), 51-59. https://www.proquest.com/scholarly-journals/choosing-celebrity-endorsers/docview/194209323/se-2?accou ntid=201395

Mollen, A., \& Wilson, H. (2010). Engagement, telepresence and interactivity in online consumer experience: Reconciling scholastic and managerial perspectives. Journal of Business Research, 63, 919-925. https://doi.org/10.1016/j.jbusres.2009.05.014

Nayeem, T., Murshed, F., \& Dwivedi, A. (2019). Brand experience and brand attitude: Examining a credibility based mechanism. Marketing Intelligence \& Planning, 37(7), 821-836. https://doi.org/10.1108/MIP-11-2018-0544

Ohanian, R. (1990). Construction and validation of a scale to measure celebrity endorsers' perceived expertise, trustworthiness, and attractiveness. Journal of Advertising, 19(3), 39-52. https://doi.org/10.1080/00913367.1990.10673191

Ohanian, R. (1991). The impact of celebrity spokespersons' perceived image on consumers' intention to purchase. Journal of Advertising Research, 31(1), 46-54. https://psycnet.apa.org/record/1991-26094-001

Pine, B. J., \& Gilmore, J. H. (1998). Welcome to the experience economy. Harvard Business Review, 4(1), 97-105. https://hbr.org/1998/07/welcome-to-the-experience-economy

Raut, U. R., Brito, P. Q., \& Pawar, P. A. (2020). Analysis of brand resonance measures to access, dimensionality, reliability and validity. Global Business Review, 21(1), 162-175. https://doi.org/10.1177/0972150919846964

Russell, C. A., \& Stern, B. B. (2006). Consumers, characters, and products: A balance model of sitcom product placement effects. Journal of Advertising, 35(1), 7-21. https://doi.org/10.2753/JOA0091-3367350101 
Schouten, A. P., Janssen, L., \& Verspaget, M. (2019). Celebrity vs. influencer endorsements in advertising: The role of identification, credibility, and product-endorser fit. International Journal of Advertising, 39(2), 258-281. https://doi.org/10.1080/02650487.2019.1634898

Sheth, J. N., Newman, B. I., \& Gross, B. L. (1991). Why we buy what we buy: A theory of consumption values. Journal of Business Research, 22(2), 159-170. https://doi.org/10.1016/0148-2963(91)90050-8

Sternthal, B., Dholakia, R., \& Leavitt, C. (1978). The persuasive effect of source credibility: Tests of cognitive response. Journal of Consumer Research, 4, 252-260. https://doi.org/10.1086/208704

Sweeney, J. C., \& Soutar, G. N. (2001). Consumer perceived value: The development of a multiple item scale. Journal of Retailing, 77, 203-220. https://doi.org/10.1016/S0022-4359(01)00041-0

Tavakol, M., \& Dennick, R. (2011). Making sense of Cronbach's alpha. International Journal of Medical Education, 2, 53-55. https://doi.org/10.5116/ijme.4dfb.8dfd

Teng, W. C., Su, Y. H., Liao, T. T., \& Wei, C. L. (2020). An exploration of celebrity business ventures and their appeal to fans and non-fans. Journal of Retailing and Consumer Services, 54. https://doi.org/10.1016/j.jretconser.2019.102004

Terblanche, N. S. (2018). Revisiting the supermarket in-store customer shopping experience. Journal of Retailing and Consumer Services, 40, 48-59. https://doi.org/10.1016/j.jretconser.2017.09.004

Thomson, M., Macinnis, D. J., \& Park, C. W. (2005). The ties that bind: Measuring the strength of consumers' attachments to brands. Journal of Consumer Psychology, 15(1), 77-91. https://doi.org/10.1207/s15327663jcp1501_10

Till, B. D., \& Busler, M. (1998). Matching products with endorsers: Attractiveness versus expertise. Journal of Consumer Marketing, 15(6), 576-586. https://doi.org/10.1108/07363769810241445

Varshneya, R., Das, G., \& Khare, A. (2017). Experiential value: A review and future research directions. Marketing Intelligence \& Planning, 35(3), 339-357. https://doi.org/10.1108/MIP-05-2016-0075

Veloutsou, C., \& Guzmán, F. (2017). The evolution of brand management thinking over the last 25 years as recorded. Journal of Product \& Brand Management, 26(1), 2-12. https://doi.org/10.1108/JPBM-01-2017-1398

Vogel, L. H. (1998). Entertainment industry economics: A guide for financial analysis. New York, NY: Cambridge University Press.

Wang, Y. (2008). Using the P-O-X balance theory to examine relationships among young adults' perception of spokesmen characteristics, advertising attitudes and Apparel attributes- A case study of apparel brands. Journal of Kaohsiung Normal University, 25, 29-50. https://doi.org/10.7060\%2fKNUJ-ES.200812.0029

Wu, L. W., Lin, C. Y., \& Lin, W. L. (2015). Celebrity endorsements in private brands: Brand familiarity, perceived risk, perceived value and brand relationship. Journal of Management Research, 15(1), 85-116.

Yu, S., \& Hu, Y. (2020). When luxury brands meet China: The effect of localized celebrity endorsements in social media marketing. Journal of Retailing and Consumer Services, 54. https://doi.org/10.1016/j.jretconser.2019.102010

Zeithaml, V. A. (1988). Consumer perceptions of price, quality, and value: A means-end model and synthesis of evidence. Journal of Marketing, 52(7), 2-22. https://doi.org/10.2307/1251446

Ministry of Culture. (2013, October 30). Overview of the development of Taiwan's pop music industry. Bureau of Audiovisual and Music Industry Development, MOC, Taiwan. Retrieved March 26, 2018, from https://www.bamid.gov.tw/information_246_64718.html

Chen, Y. R. (2015, September 23). Brand strategy: Looking at the brand from Polkadot, can celebrity endorsements definitely add credit to the brand? Expbravo. Retrieved May 24, 2021, from https://reurl.cc/NXvqM9

Zhao, M. R. (2017, December 1). Ten million revenue battle for Mayday concert - FamilyMart convenience store. Common Wealth Web Magazine. Retrieved May 25, 2021, from https://www.cw.com.tw/article/5086540

Arora, S. (2021, January 22). Customer experience value is an Entrepreneurs key to drive a brand's success: Sagun Arora. Business World. New Delhi, India: Athena Information Solutions Pvt. Ltd. Retrieved June 3, 2021, from

https://www.proquest.com/magazines/customer-experience-value-is-entrepreneurs-key/docview/247965227 
2/se-2?accountid=13204

\section{Copyrights}

Copyright for this article is retained by the author(s), with first publication rights granted to the journal.

This is an open-access article distributed under the terms and conditions of the Creative Commons Attribution license (http://creativecommons.org/licenses/by/4.0/). 